\title{
Correction to: Elective Neck Dissection Versus Observation in cT1-T2 Oral Tongue Squamous Cell Carcinoma: A Meta- Analysis of 11,973 Patients
}

\author{
Mohammad Akheel $^{1}\left(\mathbb{D} \cdot\right.$ Rinku K. George $^{1} \cdot$ Sukirti Tiwari $^{2} \cdot$ Amit Jain $^{3} \cdot$ \\ Qutubuddin Chahwala $^{4} \cdot$ Ashmi Wadhwania $^{5}$
}

Published online: 8 December 2020

(C) Association of Otolaryngologists of India 2020

\section{Correction to: Indian J Otolaryngol Head Neck Surg https://doi.org/10.1007/s12070-020-02118-y}

The article [Elective Neck Dissection Versus Observation in cT1-T2 Oral Tongue Squamous Cell Carcinoma: A Meta-Analysis of 11,973 Patients], written by [Mohammad Akheel, Rinku K. George, Sukirti Tiwari, Amit Jain, Qutubuddin Chahwala, Ashmi Wadhwania], was originally published online on [02 September 2020] with Open Access under a [This article is licensed under a Creative Commons Attribution 4.0 International License, which permits use, sharing, adaptation, distribution and reproduction in any medium or format, as long as you give appropriate credit to the original author(s) and the source, provide a link to the Creative Commons licence, and indicate if changes were made. The images or other third

The original article can be found online at https://doi.org/10.1007/s12070-020-02118-y.

Mohammad Akheel

drakheelomfs@gmail.com

Rinku K. George

rinkugeorge@gmail.com

Sukirti Tiwari

sukirti.t@gmail.com

Ashmi Wadhwania

ashmiwadhwania@gmail.com

1 Oral \& Maxillofacial Surgery, Saveetha Institute of Medical and Technical Sciences, Chennai, Tamil Nadu, India

2 Consultant Oral and Maxillofacial Surgeon, Delhi, India

3 Consultant radiation oncologist, SRJ-CBCC Cancer Centre, Indore, India

4 Consultant histopathologist, CHL Hospitals, Indore, India

5 Consultant Oral and Maxillofacial Surgeon, Indore, India party material in this article are included in the article's Creative Commons licence, unless indicated otherwise in a credit line to the material. If material is not included in the article's Creative Commons licence and your intended use is not permitted by statutory regulation or exceeds the permitted use, you will need to obtain permission directly from the copyright holder. To view a copy of this licence, visit http://creativecommons.org/licenses/by/4.0/].

With the authors' decision to cancel Open Access the copyright of the article changed on [24 September 2020] to (C) Association of Otolaryngologists of India 2020 with all rights reserved.

Publisher's Note Springer Nature remains neutral with regard to jurisdictional claims in published maps and institutional affiliations. 